\title{
Clinical profile and fetal outcome in women with preterm labor pains
}

\author{
Shweta Gupta ${ }^{1 *}$, Sunil K. Juneja ${ }^{1}$, Himanti Salhan ${ }^{1}$, Parminder Sandhu ${ }^{2}$
}

\begin{abstract}
${ }^{1}$ Department of Obstetrics and Gynecology, Dayanand Medical College and Hospital, Ludhiana, Punjab, India
${ }^{2}$ Department of Radiology, Dayanand Medical College and Hospital, Ludhiana, Punjab, India
\end{abstract}

Received: 22 August 2019

Accepted: 30 September 2019

\section{*Correspondence:}

Dr. Shweta Gupta,

E-mail: drshwetagupta114@gmail.com

Copyright: () the author(s), publisher and licensee Medip Academy. This is an open-access article distributed under the terms of the Creative Commons Attribution Non-Commercial License, which permits unrestricted non-commercial use, distribution, and reproduction in any medium, provided the original work is properly cited.

\begin{abstract}
Background: Preterm labor is a potential cause of preterm birth. Certain demographic and presenting features in pregnant women may correlate to the severity of the problem and progression to delivery. The aim of the study was to find out the clinical profile and fetal outcome in women with preterm labor pains in a tertiary care hospital of North India.

Methods: 83 women with preterm labor were included in the study. Antenatal corticosteroids and tocolytic therapy were given. Women who delivered preterm comprised of Group A and who delivered at term were Group B. Clinical profile and fetal outcome was compared and statistically analyzed.

Results: 39 (47.0\%) women had preterm delivery (Group A) and 44 (53.0\%) women delivered at term (Group B). $23.1 \%$ women in group A and $4.5 \%$ in group B had a previous preterm birth $(\mathrm{p}=0.021) .16(41 \%)$ women in group A and $4(9.1 \%)$ in group B had a positive microbial growth on high vaginal swab $(\mathrm{p}=0.001)$. The odds of having a preterm birth with cervical length of $<2 \mathrm{~cm}$ was calculated to be $5.281(\mathrm{p}=0.000)$. A statistically significant difference was observed in the mean birth weight, Apgar score and nursery admissions in both the groups $(\mathrm{p}=0.000)$.

Conclusions: A prior history of preterm birth, a positive growth on high vaginal swab and a cervical length of less than $2 \mathrm{~cm}$ were found to be significantly associated with preterm birth.
\end{abstract}

Keywords: Cervical length, Preterm birth, Preterm labor

\section{INTRODUCTION}

Preterm labor is defined as regular uterine contractions accompanied by a change in cervical dilatation, effacement, or both, or initial presentation with regular contractions and cervical dilatation of at least $2 \mathrm{~cm} .{ }^{1}$ Risk factors for preterm labor include BMI >30, Caucasian ethnicity, drug abuse, history of vaginal bleeding, gestational diabetes/ diabetes mellitus, hypertensive disorder of pregnancy, short cervical length. ${ }^{2}$

Preterm birth is one of the most common causes of perinatal morbidity and mortality in new-borns. Preterm babies are at increased risk of neurodevelopmental impairments, respiratory and gastrointestinal complications. ${ }^{3}$ Proper diagnosis and screening are, therefore, important to find out high-risk women who are at greatest risk of preterm delivery, thus allowing transport to a regional obstetrical center and permit time for corticosteroid therapy. ${ }^{4}$ Demographic, socioeconomic and psychological markers have been considered as standard primary predictors of preterm labor. ${ }^{5}$ This study was aimed to find out the clinical profile and fetal outcome in women with preterm labor pains in a tertiary care hospital of North India.

\section{METHODS}

The study was conducted in the department of Obstetrics and Gynaecology at Dayanand Medical College and 
Hospital, Ludhiana, Punjab from January 2017 till January 2018 after the approval from the hospital ethical committee. The study consisted of women with singleton pregnancy admitted in the labor room with the diagnosis of preterm onset of labor in the age group of 18 to 35 years at 28 to 34 weeks of pregnancy. The chief complaints were pain abdomen radiating to thigh and back associated with the hardening of the uterus, intermediate, increasing in intensity and duration.

Complete evaluation of the mother was done including a detailed history of all the risk factors such as gestational diabetes, hypertensive disorder of pregnancy, history of prior preterm birth, cervical cerclage, PPROM, urinary tract infection, vaginal discharge, bleeding per vaginum, family history. Gestation confirmed clinically by previous records and ultrasonography. Examination showed regular uterine contractions with cervical dilatation greater than $2 \mathrm{~cm}$. High vaginal swab taken; cervical length measured by a transvaginal scan. Exclusion criteria were women in active labor (cervical dilatation $>6 \mathrm{~cm}$ ), fetal anomaly or amniotic fluid abnormalities (oligohydramnios or polyhydramnios) detected on ultrasonography, any uterine or cervical anomaly, hypertension, diabetes, rupture of membranes, vaginal bleeding, history of smoking, alcohol intake, drug abuse, psychiatric illness, any periodontal infection.

Tocolytic therapy was given in the form of calcium channel blocker (Nifedipine) or Beta 2 agonist
(Isoxsuprine) along with the antenatal corticosteroids as per the ACOG guidelines. ${ }^{3}$ The women were followed till delivery and fetal outcome noted. They were divided into two groups:

Group A: Women who delivered preterm (before 37 completed weeks)

Group B: Women who delivered at term (37-41 weeks).

\section{Statistical analysis}

The data regarding the clinical profile and the fetal outcome in both the groups was collected, compared and statistically analyzed using the odds ratio, chi square and student's t test. Fetal outcome was judged on the basis of weight at birth, nursery admission and APGAR score at 1 min and 5 min.

\section{RESULTS}

90 women who presented with preterm onset of labor pains between 28 to 34 weeks of gestation were registered in the study. Of these, 7 women who had spontaneous rupture of membranes before the completion of tocolytic therapy were excluded. So, the study was conducted on 83 women, divided into Group A: 39 $(47.0 \%)$ women who had preterm delivery and Group B: $44(53.0 \%)$ women who delivered at term.

Table 1: Distribution of women according to age.

\begin{tabular}{|c|c|c|c|c|c|c|c|}
\hline & Gr & up A & Gr & & \multirow{2}{*}{ Total } & \multirow{2}{*}{$\begin{array}{l}\text { Chi-square } \\
\text { value }\end{array}$} & \multirow{2}{*}{ p-value } \\
\hline Age group (years) & \multicolumn{2}{|c|}{ Preterm births } & \multicolumn{2}{|c|}{ Term births } & & & \\
\hline $18-20$ & 3 & $7.7 \%$ & 0 & $0.0 \%$ & $3(3.6 \%)$ & & \\
\hline $21-30$ & 26 & $66.7 \%$ & 37 & $84.1 \%$ & $65(78.3 \%)$ & & \\
\hline $31-35$ & 8 & $20.5 \%$ & 7 & $15.9 \%$ & $15(18.1 \%)$ & 4.026 & 0.134 \\
\hline Total & 39 & $100.0 \%$ & 44 & $100.0 \%$ & 83 & & \\
\hline
\end{tabular}

Table 2: Distribution of women according to parity.

\begin{tabular}{|c|c|c|c|c|c|c|c|c|}
\hline \multirow{2}{*}{ Obstretric history } & Gr & $\mathbf{A}$ & Gr & & \multirow{2}{*}{ Total } & \multirow{2}{*}{$\begin{array}{l}\text { Chi-square } \\
\text { value }\end{array}$} & \multirow{2}{*}{$\begin{array}{l}\text { p- } \\
\text { value }\end{array}$} & \multirow{2}{*}{$\begin{array}{l}\text { Odds } \\
\text { ratio }\end{array}$} \\
\hline & \multicolumn{2}{|c|}{ Preterm births } & \multicolumn{2}{|c|}{ Term births } & & & & \\
\hline Multi-gravida & 25 & $64.1 \%$ & 22 & $50.0 \%$ & $47(56.6 \%)$ & & & \\
\hline Primi-gravida & 14 & $35.9 \%$ & 22 & $50.0 \%$ & $36(43.4 \%)$ & 1.674 & 0.196 & 1.786 \\
\hline Total & 39 & $100.0 \%$ & 44 & $100.0 \%$ & 83 & & & \\
\hline
\end{tabular}

Table 3: Distribution of women according to history of discharge per vaginum.

\begin{tabular}{|c|c|c|c|c|c|c|c|c|}
\hline \multirow{2}{*}{$\begin{array}{l}\text { History of vaginal discharge } \\
\text { Negative }\end{array}$} & \multirow{2}{*}{\multicolumn{2}{|c|}{$\begin{array}{l}\text { Group A } \\
\text { Preterm births }\end{array}$}} & \multirow{2}{*}{\multicolumn{2}{|c|}{$\begin{array}{l}\text { Group B } \\
\text { Term births }\end{array}$}} & \multirow{2}{*}{$\begin{array}{l}\text { Total } \\
54(65.1 \%)\end{array}$} & \multirow{2}{*}{$\begin{array}{l}\text { Chi-square } \\
\text { value }\end{array}$} & \multirow{2}{*}{$\begin{array}{l}\mathrm{p} \text { - } \\
\text { value }\end{array}$} & \multirow{2}{*}{$\begin{array}{l}\text { Odds } \\
\text { ratio }\end{array}$} \\
\hline & & $\begin{array}{c}\text { n births } \\
61.5 \%\end{array}$ & & & & & & \\
\hline Positive & 15 & $38.5 \%$ & 14 & $31.8 \%$ & $29(34.9 \%)$ & \multirow[t]{2}{*}{0.401} & \multirow[t]{2}{*}{0.526} & \multirow[t]{2}{*}{1.339} \\
\hline Total & 39 & $100.0 \%$ & 44 & $100.0 \%$ & 83 & & & \\
\hline
\end{tabular}


The minimum age was 18 years and maximum 35 years with a mean of 27.7 years. Maximum 65 (78.3\%) number of women were from age group of 21 to 30 years out of which $66.7 \%$ were of Group A and $84.1 \%$ of Group B. No statistically significant difference was observed $(\mathrm{p}=0.134)$ (Table 1).

Table 4: Distribution of women according to family history of preterm birth.

\begin{tabular}{|c|c|c|c|c|c|c|c|c|}
\hline \multirow{2}{*}{ Family history of preterm birth } & \multirow{2}{*}{\multicolumn{2}{|c|}{$\begin{array}{l}\text { Group A } \\
\text { Preterm births }\end{array}$}} & \multirow{2}{*}{\multicolumn{2}{|c|}{$\begin{array}{l}\text { Group B } \\
\text { Term births }\end{array}$}} & \multirow{2}{*}{ Total } & \multirow{3}{*}{$\begin{array}{l}\text { Chi-square } \\
\text { value }\end{array}$} & \multirow{3}{*}{$\begin{array}{l}p \text { - } \\
\text { value }\end{array}$} & \multirow{2}{*}{$\begin{array}{l}\text { Odds } \\
\text { ratio }\end{array}$} \\
\hline & & & & & & & & \\
\hline Negative & 33 & $84.6 \%$ & 38 & $86.4 \%$ & $71(85.5 \%)$ & & & \multirow{3}{*}{1.152} \\
\hline Positive & 6 & $15.4 \%$ & 6 & $13.6 \%$ & $12(14.5 \%)$ & \multirow[t]{2}{*}{0.051} & \multirow[t]{2}{*}{0.821} & \\
\hline Total & 39 & $100.0 \%$ & 44 & $100.0 \%$ & 83 & & & \\
\hline
\end{tabular}

Table 5: Comparison of women according to history of preterm birth.

\begin{tabular}{|c|c|c|c|c|c|c|c|c|}
\hline \multirow{3}{*}{$\begin{array}{l}\text { History of preterm birth } \\
\text { Negative }\end{array}$} & \multirow{2}{*}{\multicolumn{2}{|c|}{$\begin{array}{l}\text { Group A } \\
\text { Preterm births }\end{array}$}} & \multirow{2}{*}{\multicolumn{2}{|c|}{$\begin{array}{l}\text { Group B } \\
\text { Term births }\end{array}$}} & \multirow{3}{*}{$\begin{array}{l}\text { Total } \\
72(86.7 \%)\end{array}$} & \multirow{3}{*}{$\begin{array}{l}\text { Chi-square } \\
\text { value }\end{array}$} & \multirow{3}{*}{$\begin{array}{l}\mathrm{p} \text { - } \\
\text { value }\end{array}$} & \multirow{2}{*}{$\begin{array}{l}\text { Odds } \\
\text { ratio }\end{array}$} \\
\hline & & & & & & & & \\
\hline & 30 & $76.9 \%$ & 42 & $95.5 \%$ & & & & \multirow{3}{*}{6.3} \\
\hline Positive & 9 & $23.1 \%$ & 2 & $4.5 \%$ & $11(13.3 \%)$ & \multirow[t]{2}{*}{6.176} & \multirow[t]{2}{*}{$0.021^{*}$} & \\
\hline Total & 39 & $100.0 \%$ & 44 & $100.0 \%$ & 83 & & & \\
\hline
\end{tabular}

*statistically significant.

There were $64.1 \%$ women in Group A were multigravida (having borne more than one child) as compared to $35.9 \%$ in Group B. $50.0 \%$ were primigravida (pregnant for the first time) in Group A. The Odds ratio was 1.786 and the distribution statistically non-significant $(\mathrm{p}=0.196)$ (Table 2). All the women included in our study were of Indian origin with no comparison of race and all belonged to the upper middle class according to the modified Kuppuswamy scale of socioeconomic strata.
Table 3 shows the comparison of women understudy according to presence of history of discharge per vaginum. No statistically significant difference was observed in both the groups (odds ratio $=1.339$ ) $(\mathrm{p}=0.526)$. In group $\mathrm{A}, 6(15.4 \%)$ and in group $\mathrm{B}, 6$ $(13.6 \%)$ women had a positive family history of preterm birth in previous pregnancy. Though the Odds ratio was greater than 1 (1.152), but the difference statistically nonsignificant $(\mathrm{p}=0.821)$ (Table 4$)$.

Table 6: Comparison of women according to results of high vaginal swab culture.

\begin{tabular}{|c|c|c|c|c|c|c|c|c|}
\hline \multirow{2}{*}{ High vaginal swab culture } & \multicolumn{2}{|c|}{ Group A } & \multicolumn{2}{|c|}{ Group B } & \multirow{2}{*}{ Total } & \multirow{2}{*}{$\begin{array}{l}\text { Chi-square } \\
\text { value }\end{array}$} & \multirow{2}{*}{$\begin{array}{l}\mathrm{p}- \\
\text { value }\end{array}$} & \multirow{2}{*}{$\begin{array}{l}\text { Odds } \\
\text { ratio }\end{array}$} \\
\hline & Pre & rm births & Tel & irths & & & & \\
\hline Negative & 23 & $59.0 \%$ & 40 & $90.9 \%$ & 63 & \multirow{3}{*}{11.528} & \multirow{3}{*}{$0.001 *$} & \multirow{3}{*}{6.957} \\
\hline Positive & 16 & $41.0 \%$ & 4 & $9.1 \%$ & 20 & & & \\
\hline Total & 39 & $100.0 \%$ & 44 & $100.0 \%$ & 83 & & & \\
\hline
\end{tabular}

*statistically significant

Table 7: Comparison of women according to cervical length.

\begin{tabular}{|c|c|c|c|c|c|c|c|c|}
\hline \multirow{2}{*}{ Cervical length (cm) } & \multicolumn{2}{|c|}{ Group A } & \multicolumn{2}{|c|}{ Group B } & \multirow{2}{*}{ Total } & \multirow{2}{*}{$\begin{array}{l}\text { Chi-square } \\
\text { value }\end{array}$} & \multirow{2}{*}{$\begin{array}{l}\text { p- } \\
\text { value }\end{array}$} & \multirow{2}{*}{$\begin{array}{l}\text { Odds } \\
\text { ratio }\end{array}$} \\
\hline & $\operatorname{Pr}$ & rm births & Ter & irths & & & & \\
\hline$>2$ & 7 & $17.9 \%$ & 43 & $97.7 \%$ & 50 & \multirow{3}{*}{54.939} & \multirow{3}{*}{$0.000 *$} & \multirow{3}{*}{5.281} \\
\hline$\leq 2$ & 32 & $82.1 \%$ & 1 & $2.3 \%$ & 33 & & & \\
\hline Total & 39 & $100.0 \%$ & 44 & $100.0 \%$ & 83 & & & \\
\hline
\end{tabular}

*statistically significant

There were $23.1 \%$ women in Group A and $4.5 \%$ in Group B women had a previous preterm birth, the difference being statistically significant $($ Odds ratio=6.3) $(\mathrm{p}=0.021)$.
Hence, a prior history of preterm birth has more odds of having a preterm birth than women with no such history (Table 5). No statistically significant difference $(p=0.274)$ 
was observed in BMI of women of both the groups; the mean was $24.13 \mathrm{~kg} / \mathrm{m}^{2}$ in Group $\mathrm{A}$ and $23.16 \mathrm{~kg} / \mathrm{m}^{2}$ in Group B. $16(41 \%)$ women in group A and $4(9.1 \%)$ in group $\mathrm{B}$ had a positive microbial growth on high vaginal swab; the data was statistically significant $(p=0.001)$. The Odds ratio of having preterm birth was calculated to be 6.957 (Table 6). Most common bacteria were E.coli followed by Candida, Klebsiella pneumonia and Staphylococcus heamolyticus. $32(82.1 \%)$ women in Group A and $1(2.3 \%)$ in Group B had cervical length less than $2 \mathrm{~cm}$ measured by a transvaginal ultrasound on admission. The odds of having preterm birth with cervical length of less than $2 \mathrm{~cm}$ was calculated to be $5.281(\mathrm{p}=0.000)$ (Table 7).

A statistically significant difference was observed in the mean birth weight, Apgar score and nursery admissions in both the Groups. 35 (89.7\%) neonates in Group A and $2(4.5 \%)$ in Group B required nursery admission $(\mathrm{p}=0.000)$. The mean birth weight was $1.69 \mathrm{~kg}$ in Group A and $2.94 \mathrm{~kg}$ in Group B. Mean APGAR score in Group $A$ at 1 and 5 min respectively was 7 and 8 (rounded off) as compared to 8 and 9 in Group B (Table 8).

Table 8: Comparison of women according to fetal outcome.

\begin{tabular}{|c|c|c|c|c|c|c|}
\hline \multirow{3}{*}{ Neonatal parameters } & \multicolumn{2}{|c|}{ Group A } & \multicolumn{2}{|c|}{ Group B } & \multirow{3}{*}{$\mathrm{t}$} & \multirow{3}{*}{ p-value } \\
\hline & \multicolumn{2}{|c|}{ Preterm births } & \multicolumn{2}{|c|}{ Term births } & & \\
\hline & Mean & SD & Mean & SD & & \\
\hline Birth weight (kg) & 1.69 & 0.36 & 2.94 & 0.34 & -16.449 & $0.000 *$ \\
\hline APGAR Score $1 \mathrm{~min}$ & 6.41 & 0.68 & 7.73 & 0.45 & -10.537 & $0.000 *$ \\
\hline APGAR score $5 \mathrm{~min}$ & 7.64 & 0.67 & 8.93 & 0.25 & -11.880 & $0.000^{*}$ \\
\hline
\end{tabular}

*statistically significant.

\section{DISCUSSION}

The mean age found in our study was 27.64 years in Group A and 27.66 years in Group B. This is in contrast to a large retrospective study done by Fuchs $\mathrm{F}$ et al, in which advanced maternal age (40 years and over), and younger women (20-24 years) had an increased risk of preterm birth. ${ }^{6}$

Authors did not observe any significant difference in the distribution of primigravida and multigravida women in preterm labor $(p=0.196)$. Similar observation was made by Shah PS in a systematic review comprising of 41 studies where no statistical difference was seen in the incidence of preterm delivery in primigravida, multigravida, and grand multigravida. ${ }^{7}$ This is in accordance with other studies where this factor was not considered as a maternal variable which influences preterm labour. ${ }^{5}$

In this study, all patients were of Indian origin, and all belonged to the upper middle class. So, we cannot document the effect of ethnicity and socioeconomic status on preterm labor. However, Burris $\mathrm{HH}$ et al concluded that racial disparities and environmental factors play a role in the incidence of preterm birth. ${ }^{8}$

Vaginal discharge was a symptom in 29 (39.4\%) women in our study. However, positive correlation with preterm birth could not be made out as the data was equally distributed in both the groups $(\mathrm{p}=0.5)$. This is in contrast to a study done by Fonseca TM et al, in Brazil which showed that history of pathological vaginal discharge during pregnancy was significantly associated with threatened premature labour. ${ }^{9}$

We did not observe a significant correlation between a positive family history of preterm birth and preterm delivery $(p=0.821)$. This is in contrast to a study published by Sherf $\mathrm{Y}$ et al, which concluded that family history of preterm delivery is an independent risk factor for recurrence of preterm birth in the subsequent generation. $^{10}$

A significant correlation $(\mathrm{p}=0.021)$ was observed between history of preterm birth in the previous pregnancy and risk of preterm birth in subsequent pregnancies. Comparable results were obtained by Mercer et al, who performed an analysis to evaluate the association between prior spontaneous preterm birth and subsequent pregnancy outcome. ${ }^{11}$ In our study, basal metabolic Index (BMI) had no statistically significant difference in both the groups $(p=0.274)$. However, Vinturache $\mathrm{A}$ et al, found an increased risk of spontaneous preterm birth in nulliparous women with increasing BMI, and also observed an association in overweight and mildly obese women with preterm birth but not in moderate and severely obese women. ${ }^{12}$ Hence it can be concluded that there is a certain amount of uncertainty regarding the relationship between BMI and preterm birth and more studies are required to reach a conclusion.

Our study shows a positive correlation between a positive high vaginal culture and preterm birth $(\mathrm{p}=0.01)$. Similar results were published by Shivaraju $\mathrm{P}$ et al, which revealed that there were increased odds of preterm 
delivery in women with positive high Vaginal swab cultures. ${ }^{13,14}$ The reason behind this can be explained by the fact that the microorganisms such as E. Coli, S. Aureus, Group B Streptococcus, Klebsiella Species and Enterococci can induce inflammatory responses in the female genital tract. These responses are potentially important factors in the pathogenesis of preterm labour. ${ }^{3}$

ACOG defines short cervix as cervical length less than $2.5 \mathrm{~cm}$ before 24 weeks. $^{1}$ The relationship of short cervical length in early pregnancy and preterm labour has been well documented and has been observed in our study $(p=0.000)$. However, limited studies are available to determine the cut off for the length of the cervix after 24 weeks. In order to find a relationship between cervical lengths in women with preterm labor from 28 to 34 weeks, we took a cut off of $2 \mathrm{~cm}$. The Odds ratio of having preterm birth with a cervical length of less than 2 $\mathrm{cm}$ was calculated to be 5.281. A limited number of studies have been done to determine the role of 3rdtrimester cervical length in the prediction of preterm labor. In a study done by Goldenberg et al in women who delivered before 32 weeks, they observed an odds ratio of 5.6 in women more than 24 weeks with preterm labor and cervical length less than $2 \mathrm{~cm}^{3}$ Similarly, a positive correlation of cervical length with preterm labor was published by Shahshahan $\mathrm{Z}$ et al, with best cut off calculated as $2.2 \mathrm{~cm}^{4}$

This study included 83 women between the gestational age of 28 to 34 weeks with preterm labor. All the women were administered corticosteroids and tocolysis therapy and were followed till delivery. Of these, $53.0 \%$ delivered at term and a significant difference was observed in the fetal outcome. Singh $U$ et al, stated the significance of betamethasone in preventing neonatal comorbidities, reducing the financial and emotional burden on parents. ${ }^{15}$

\section{CONCLUSION}

Preterm labor and preterm birth are the obstetrical entities that mandate the need for prolonged hospital stay for the mother and the baby. This results in huge psychological and financial burden on the parents and the society. As the etiological factors can be easily recognized on routine antenatal visits and ultrasonography; these at-risk mothers should be given timely care and treatment in order to prolong the pregnancy and improve fetal outcome.

Funding: No funding sources Conflict of interest: None declared

Ethical approval: The study was approved by the Institutional Ethics Committee

\section{REFERENCES}

1. American College of Obstetricians and Gynecologists' Committee on Practice Bulletins-Obstetrics. Practice Bulletin No. 171: Management of Preterm Labor. Obstet Gynecol. 2016;128(4):e155-64

2. Dekker GA, Lee SY, North RA, McCowan LM, Simpson $\mathrm{N}$, Roberts CT. Risk factors for preterm birth in an international prospective cohort of nulliparous women. PLOS ONE. 2012;7(7):e39154.

3. Goldenberg RL, Culhane JF, Iams JD. Epidemiology and causes of preterm birth. Lancet. 2008;371:75-84.

4. Shahshahan Z, Iravani H. Comparison of CRP and ALK-P serum levels in the prediction of preterm delivery. Adv Biomed Res. 2016;5:17.

5. Goffinet F. Primary predictors of preterm labour. BJOG: Int J Obstet Gynaecol. 2005;112:38-47.

6. Fuchs F, Monet B, Ducruet T, Chaillet N, Audibert F. Effect of maternal age on the risk of preterm birth: A large cohort study. PloS one. 2018;13(1):e0191002.

7. Shah PS. Parity and low birth weight and preterm birth: a systematic review and meta-analyses. Acta Obstet Gynecol Scand. 2010;89(7):862-75.

8. Burris HH, Collins JW, Wright RO. Racial/ethnic disparities in preterm birth: clues from environmental exposures. Curr Opin Pediatr. 2011;23(2):227-32.

9. Fonseca TM, Cesar JA, Mendoza-Sassi RA, Schmidt EB. Pathological vaginal discharge among pregnant women: pattern of occurrence and association in a population-based survey. Obstet Gynecol Int. 2013;2013:590416.

10. Sherf Y, Sheiner E, Vardi IS, Sergienko R, Klein J, Bilenko N. Recurrence of preterm delivery in women with a family history of preterm delivery. Am J Perinatol. 2016;34(04):397-402.

11. Mercer BM, Goldenberg RL, Moawad AH, Meis PJ, Iams JD, Das AF, et al. The preterm prediction study: effect of gestational age and cause of preterm birth on subsequent obstetric outcome. National Institute of Child Health and Human Development Maternal-Fetal Medicine Units Network. Am J Obstet Gynecol. 1999;181(5 Pt 1):1216-21.

12. Vinturache A, McKeating A, Daly N, Sheehan S, Turner M. Maternal body mass index and the prevalence of spontaneous and elective preterm deliveries in an Irish obstetric population: a retrospective cohort study. BMJ Open. 2017;7(10):e015258.

13. Shivaraju P, Purra $P$, Bheemagani N, Lingegowda K. Vaginal infections and its relation to preterm labour, PPROM, PROM and its outcome. Int J Reprod Contracept Obstet Gynecol. 2015;4(5):1422-6.

14. Jamal S, Srivastava R. A retrospective analytical study of the epidemiology and causes of preterm birth. Int J Reprod Contracept Obstet Gynecol. 2017;6(12):5453-7.

15. Singh U, Singh N, Seth S. A prospective analysis of etiology and outcome of preterm labor. J Obstet Gynecol India. 2007;57:48-52.

Cite this article as: Gupta S, Juneja SK, Salhan H, Sandhu P. Clinical profile and fetal outcome in women with preterm labor pains. Int J Reprod Contracept Obstet Gynecol 2019;8:4309-13. 